\title{
Family violence against children in the wake of COVID-19 pandemic: a review of current perspectives and risk factors
}

\author{
Noemí Pereda* ${ }^{*}$ and Diego A. Díaz-Faes [D
}

\begin{abstract}
The situation of crisis produced by the Coronavirus (COVID-19) pandemic poses major challenges to societies all over the world. While efforts to contain the virus are vital to protect global health, these same efforts are exposing children and adolescents to an increased risk of family violence. Various criminological theories explain the causes of this new danger. The social isolation required by the measures taken in the different countries, the impact on jobs, the economic instability, high levels of tension and fear of the virus, and new forms of relationships have all increased levels of stress in the most vulnerable families and, therefore, the risk of violence. In addition, mandatory lockdowns imposed to curb the spread of the disease have trapped children in their homes, isolating them from the people and the resources that could help them. In general, the restrictive measures imposed in many countries have not been accompanied by an analysis of the access to the resources needed to reduce this risk. It is necessary to take urgent measures to intervene in these high-risk contexts so that children and adolescents can develop and prosper in a society which is likely to undergo profound changes, but in which the defense of their rights and protection must remain a major priority.
\end{abstract}

Keywords: COVID-19, Violence, Developmental victimology, Risk factors, Children

\section{Background}

In terms of their frequency and impact, violence and exposure to violence in the immediate family context are among the most serious forms of victimization [1]. These forms of victimization usually may include physical abuse, psychological or emotional abuse, sexual abuse, neglect, and exposure to intimate partner violence [2]. The worldwide estimations of prevalence in self-report surveys are $22.6 \%$ for physical abuse, $36.3 \%$ for emotional abuse, $7.6 \%$ among boys and $18 \%$ among girls for sexual abuse, $16.3 \%$ for physical neglect, and $18.4 \%$ for emotional neglect [3]. Regarding childhood exposure to

*Correspondence: npereda@ub.edu

Grup de Recerca en Victimització Infantil i Adolescent (GReVIA), Facultat de Psicologia," Universitat de Barcelona, Passeig Vall d'Hebron, 171, 08035 Barcelona, Spain intimate partner violence, the data available are still limited [4]; however, it is estimated that between 133 and 275 million children are exposed to this kind of violence each year [5]. In spite of the gaps in the measurement of child victimization [6], these high rates of violence and exposure to family violence reveal that interpersonal violence against children constitutes a serious global social and health problem [7].

As the COVID19 crisis continues, societies all over the world are trying to mitigate its effects in both the short and the long term. Besides looking at the risks and consequences for the mental health of children and adolescents arising from the pandemic and the measures imposed to control it [8], a criminological approach, in which the restrictive emergency measures adopted to slow the spread of the virus take into account the risk of family violence, is also essential. Social distancing, school 
and business closures, lockdown measures, and travel restrictions may reduce the transmission of the infectious disease, but they may also increase the risk of violence against children and youth around the world [9].

For violence researchers, the measures taken in response to COVID-19 present an extraordinary opportunity to advance our understanding of the social, psychological, economic and situational mechanisms that influence rates of violence [10]. In fact, contexts associated with pandemics create an environment in which children's socioecological systems are disrupted and, as a result, the incidence of child maltreatment is likely to increase [11]. However, many child welfare organizations around the world are noting a significant drop in reports of child abuse or neglect [12]. We know little about the amount of violence that children and adolescents have faced in their homes since the beginning of the pandemic, and institutions like UNICEF [13] have discouraged the performance of epidemiological studies in children unless their protection can be guaranteed. Thus, it is necessary to intervene indirectly by detecting contexts of risk and by exploring the factors that may increase violence against children and youth so as to be able to take successful action.

Therefore, the main objective of this narrative review is to describe the risk factors for violence against children that the situational context derived from COVID-19 may have generated in families around the world, and to assess them from a criminological perspective. In order to gather the latest evidence, we conducted a search of several databases that identify published and preprint research (i.e., PubMed, PsycINFO, Web of Science, Scopus, SSRN, and Google Scholar). The search terms were focused on family violence against children, risk factors and theoretical models, and crisis contexts and/or COVID-19. Here we review the theoretical and empirical studies published to date on the topic of child maltreatment and COVID-19. We also include some references on previous crises and disasters to assess the relevance of those results to the current situation. Finally, we try to explain the more than likely high risk of child abuse during the COVID-19 crisis in the light of criminological, psychological and sociological theories.

\section{Increasing risk of violence against children during the COVID-19 pandemic}

The COVID-19 pandemic may have entailed major changes for many children and their families, not just because of the lockdown, restricted measures, social isolation, changing demographics and the reduction of available health services [14], but also due to the sudden and possibly long-term increase in child poverty and family uncertainty [15]. The pandemic represents a global crisis not only for our health and economy, but also for family well-being through a cascading process of factors that can drive, precipitate or exacerbate potential stressors [16]. The situation generated by COVID-19 has few precedents, but we can build on the work in crisis or emergency situations where scenarios of rapidly increasing stress are accompanied by abrupt changes to prior conditions (see the review by [17]).

The effects of disasters and mass violence on individual development can be described in relation to the exposure dose or cumulative risks that pose significant threats or disturbances to individuals, families, or communities [18]. Thus, the COVID-19 pandemic has been conceptualized as a multisystem cascading global disaster in which children's lives have been dramatically disrupted at many levels and for which our societies were unprepared [19]. Indeed, research on COVID-19 is beginning to show the negative outcomes of the lockdown and the restrictions imposed as well as the effects of social stressors on family members, and highlights the need for longitudinal examination of children's and adolescents' mental health [20]. Emerging evidence on both healthy parenting and the mental health of children and adolescents stresses that the magnitude of the impact depends on vulnerability factors such as developmental age, previous mental health conditions, educational and socioeconomic status, or being quarantined [21].

This dramatically changing context also needs to be understood in order to address the risk of violence against children and adolescents, which is essential if our aim is to prevent or detect these cases before the consequences of this violence are irremediable. In this paper we analyze the risk factors for violence against this population from the perspective of criminological theories and socio-ecological models.

\section{Increased risk of violence through the lens of criminological theories}

Criminological theories address the multiple variables that contribute to family violence and child abuse, and can also explain why there is a greater risk of violence in critical situations. The intergenerational transmission of violence summed up in the term 'violence begets violence', is one of the prevalent assumptions in the literature: i.e., that the experience of childhood violence and/ or neglect increases the risk of perpetrating violence in later life [22]. Due to the complexity of the concept, our understanding of intergenerational transmission of violence is still limited [23]. Several theories have endeavored to explain the mechanisms involved, such as social learning theories [24], social information processing theory [25] attachment theory [26], and social control theory [27]. 
In addition, neurobiological studies have revealed the impact of chronic stress due to an abusive childhood, which may cause a neurobiological deregulation that affects neurological and brain development and modifies the response to stress related to violent behavior [28]. Evolutionary behavioral genetics explains the probability that violent parents beget violent children through various mechanisms such as trait inheritance or epigenetic changes predisposing to violent behavior [29].

However, an excessive focus on experiences of child abuse may turn out to be a static or limited, or may even interpret the later consequences as a direct product of the early exposures. Equally, the influence of genetics on violent behavior may be moderated by environmental conditions. Therefore, nature and nurture should be considered not as distinct and separate factors but as part of the same process in human behavior and, in this case, in the violence perpetrated against children in times of crisis [30]. Thus, for a more comprehensive analysis, ecological and contextual factors need to be addressed.

Environmental and situational theories help to understand children's vulnerability and the contexts that are most conducive to violence against them. Social disorganization theory proposes that neighborhood characteristics such as poverty, residential mobility, population density, overcrowding or urban blight hinder or prevent community cohesion, which lead to the increased levels of disadvantage and disorder associated with high rates of child abuse [31]. Theories of situational opportunity [32] help to understand the change in prior conditions, attributing the greater likelihood of violence to perpetrators' increased access to victims due to confinement and limitations on mobility.

Two approaches that combine and integrate some elements of the above frameworks or address the same correlates, though from different angles, are the general strain theory, which applies a sociological perspective, and target congruence theory, which applies a developmental victimology approach. General strain theory can contribute to explaining family violence and child abuse from both a proximal and a distal perspective, since it focuses on the impact of negative emotions such as anger, frustration, and resentment on the subsequent violent behavior [33]. The effect may be distal if it derives from childhood or long-term processes (e.g., adverse childhood experiences), or proximal if it derives from sudden events or situations, or it may be a confluence of both. Applied to the COVID-19 pandemic, the general strain theory posits that the interaction of the family and parents' or caregivers' background with the increase in stress and intra-family tension caused by the accumulation of risk factors linked to the emergency (and the measures imposed to control it) produces an increase in violence.
Finkelhor and Asdigian's [34] target congruence theory presents three explanatory factors for the increase in violence against children. Thus, (a) the vulnerability of potential victims, due to characteristics of the context or of the victims themselves that increase the likelihood of victimization, such as their dependence on an adult, their physical weakness, and their greater social isolation; (b) the satisfaction or gratificability generated by the use of violence, whether sexual in the case of sexual abuse and assaults, or as a way of discharging tension in the use of physical and emotional violence; and (c) antagonism, linked to characteristics or attributes of the child that arouse impulses of rejection or violence in the victimizer, such as constant requests for attention and care.

Indeed, the factors and mechanisms displayed converge and interact with the various social stressors [35] triggered or exacerbated by the COVID-19 pandemic. Their study will help to establish whether the body of knowledge accumulated by criminological theories is sufficient to identify some of the pathways that lead towards the perpetration of violence against the young, and also whether the response to the pandemic situation may favor the development of more comprehensive approaches to victimization in this age group.

\section{Increased risk of violence through the lens of socioecological models}

Socioecological accounts can provide a general framework of how the COVID-19 pandemic has directly or indirectly disrupted social ecologies and modified the interaction between individuals and their environment. The changes in this reciprocal relationship may provide new definitions for individuals' cognitions, emotions, behaviors and the underlying associated mechanisms. So, this mutual process manifests itself in changing physical, interpersonal, economic and political environments and in the ways in which humans adapt and modify these environments [36]. Given that child maltreatment is an interactional phenomenon, the COVID-19 crisis has altered children's ecological systems at a variety of levels. It has generated or aggravated a series of risk factors for child abuse and neglect pertaining to the characteristics of the child and caregivers, family dynamics, and the wider social and cultural environment. For this reason, we assess these risks through the lens of Belsky's [37] ecological integration model at its various levels. Within this model, we also consider the transactional process [38] which entails that at each ecological level the complex interaction between potentiating and compensatory factors influences both children themselves and their ecological systems. Ecological levels of analysis capture and systematize the multiple variables contributing to child abuse, but also allow the incorporation 
of complementary approaches such as sociocognitive approaches to parenting that can help to understand how environmental changes influence the incidence of child abuse [39].

At the level of the microsystem, increased oppositional behavior and limit testing are expected in children. This conduct may elicit harsh responses from parents [40], who may themselves be undergoing parental burnout, either driven or exacerbated by the consequences of the pandemic [41]. Children's own stress and uncertainty about the pandemic may add to the tension felt by their parents. The COVID-19 pandemic may also worsen existing mental health problems and trigger more cases among children and adolescents [42], thus increasing tension within the home. A recent study found that since the start of the pandemic more than 1 in 4 parents reported worsening mental health in their children, 1 in 7 parents reported worsening behavioral health, and nearly 1 in 10 reported worsening in both [43]. Children with special education needs are also at risk; they may become frustrated and short-tempered due to the disruption of their daily routines [44]. Overall, stressed parents are more likely to respond to their children's anxious behaviors or demands in aggressive or abusive ways. Initial research has shown that the situation caused by the COVID-19 crisis is highly demanding and challenging for parents and significantly increases their global levels of stress [45]. Previous research has also confirmed that a high-stress home environment is often a major predictor of physical abuse and neglect of children [46].

Parental alcohol consumption at home (as a result of the closure of pubs, bars and hotels) in order to manage stress and tension can also contribute to increasing violence against children [47], as can the presence of pre-existing mental disorders in parents and the lack of monitoring or medication [48]. Parents are under stress and the COVID-19 is changing family life [49]: children are out of school or childcare, and do not have access to group activities, team sports, or playgrounds. Parents have to keep them busy and safe while at the same time attempting to work at home; indeed, they may be unable to work due to their child care duties. Evidence of common correlates suggests that conflicts and violence between parents probably target children as well [50]. The higher increased risk of violence between the parents during quarantine due to COVID-19 might has made it particularly difficult to meet the children's needs [51].

At the level of the exosystem, or society at large, the economic consequences of the crisis are also risk factors [52]. Lost income, cumulative material adversity and housing hardships are the main predictors of child maltreatment [53]. For those living in low-income and crowded households without open spaces, challenges posed by COVID-19 are exacerbated [49]. Social isolation, in turn, prevents the detection of situations of abuse by people outside the family and stops the parents from seeing other models of relationships with children not based on violence, limiting accessible and familiar support options [54]. While the dramatic decline in social interactions is likely to have limited the contact of children with a wide range of potential reporters of child maltreatment including pediatricians and extended family members, the forced closure of nurseries and schools may also have significantly affected both the reporting and the incidence of cases of child maltreatment; this is especially worrying in view of the low levels of reporting in normal conditions [55]. Public nurseries represent an important protective factor against maltreatment [56] but their ability to play this role has been curtailed by COVID-19. Also, school closures have meant an estimated 27\% decline in the reported allegations of abuse, neglect, or abandonment of children made to the Florida Child Abuse Hotline during March and April 2020, a reduction very similar to that seen in normal times when school is out of session [57]. In addition, the resources that many at-risk parents rely on are no longer available in many areas in times of crisis. Recent research has highlighted the restrictions experienced by the NGOs around the world in their attempts to provide services to vulnerable children and families during confinement [58].

Finally, with regard to culture, attitudes towards children and their rights constitute a key risk factor for violence in the COVID-19 context. Even though research has shown that children are not the main drivers of the pandemic [59], in many countries they have been accused of being vectors of transmission of the virus, even by official leaders, and are considered more contagious than asymptomatic adults. This may have led to a degree of social rejection and may have engendered a lack of empathy for the serious consequences of home-confinement for their development and well-being [60]. In fact, even though adult society is returning to normal, schools, kindergartens or even playgrounds in most countries remain closed [61]. The treatment of this crisis is absolutely adult-centered-that is, focused on the needs and criteria of adults-and has neglected the needs of the most vulnerable and their protection. The UN Convention on the Rights of the Child is being ignored in most countries, both during the lockdown and since [62]. As a result, the increase in violence against children both during and since the pandemic may even surpass the substantial increase characteristically observed in reports following natural disasters and other catastrophic events.

In view of the above, some of the core principles of the risk-need-responsivity model [63] could be applied to the prevention of child victimization [64]. Knowledge 
of the risk factors is vital for preventing or reducing violence, and for identifying the most suitable forms of support and intervention in order to address these risks in a proportionate manner. This is a crucial aspect considering that methods of prevention will need to adapt to the post-COVID-19 scenario.

\section{Conclusion}

The present review is one of the few studies to date that has focused on the risk factors for family violence against children and youth related to the COVID-19 pandemic. We have sought to explain this risk through the application of criminological theories and socioecological models, stressing the importance of the social sciences when dealing with a pandemic and its massive global health consequences [65]. We can conclude that, in the unprecedented situation produced by the COVID-19 crisis, the risk of victimization of children and adolescents is high. The repercussions of the COVID-19 pandemic go far beyond the measures to prevent disease transmission and reduce its impact on the global population [66]. Child victim services and family violence victim-serving professionals must be prepared for the likely increases in victimization rates both during and long after this pandemic. They must address the new obstacles and look for innovative solutions based on a community-centered approach [67]. It is also vital to identify high-risk contexts in order to avoid the occurrence of long-term new acts of violence [68]. Although an initial rise in family violence is generally observed during the acute phase of a crisis, the fact we need to keep in mind is that these surges are often sustained for years during the recovery period and require a prevention strategy that offers long-term solutions [69]. The potential consequences of increased child maltreatment should be considered in future cost-benefit calculations of lockdown measures. Since family violence must be seen as a possible public health consequence of the COVID-19 pandemic, governments should work together with social care and health care providers to integrate child maltreatment into future plans for disaster risk reduction and preparedness [70]. It is crucial to learn as much as possible from this disaster to prepare for similar (or totally unprecedented) crisis situations in the future [19]. We should take the necessary measures to enable children and adolescents to develop and prosper in a society which is likely to be very different, but in which the defense of their rights and well-being must continue to be a priority.

Acknowledgements

Not applicable.

\section{Authors' contributions}

NP, and DA contributed to the design and implementation of the review, to the analysis of the studies included and to the writing of the manuscript. Both authors read and approved the final manuscript.

\section{Funding}

This review was supported by the ICREA Academia programme 2016.

\section{Availability of data and materials \\ Not applicable.}

Ethics approval and consent to participate

Not applicable.

Consent for publication

Not applicable.

Competing interests

The authors declare that they have no competing interests.

Received: 15 July 2020 Accepted: 7 October 2020

Published online: 20 October 2020

\section{References}

1. Kendall-Tackett KA. Treating the lifetime health effects of childhood victimization. Kingston: Civic Research Institute; 2003.

2. Higgins DJ, McCabe MP. Multiple forms of child abuse and neglect: adult retrospective reports. Aggress Violent Behav. 2001;6(6):547-78. https:// doi.org/10.1016/S1359-1789(00)00030-6.

3. Stoltenborgh M, Bakermans-Kranenburg MJ, Alink LRA, y van IJzendoorn $\mathrm{MH}$. The prevalence of child maltreatment across the globe: review of a series of metaanalyses. Child Abuse Rev. 2015;24:37-50. https://doi. org/10.1002/car.2353.

4. Latzman NE, Vivolo-Kantor AM, Clinton-Sherrod AM, Casanueva C, Carr C. Children's exposure to intimate partner violence: a systematic review of measurement strategies. Aggress Violent Behav. 2017;37:220-35. https:// doi.org/10.1016/j.avb.2017.10.009.

5. Pinheiro PS. World report on violence against children. Geneva: United Nations; 2006. https://resourcecentre.savethechildren.net/node/2999/ $\mathrm{pdf} / 2999 . \mathrm{pdf}$.

6. Saini SM, Hoffmann CR, Pantelis C, Everall IP, Bousman CA. Systematic review and critical appraisal of child abuse measurement instruments. Psychiatry Res. 2019;272:106-13. https://doi.org/10.1016/j.psych res.2018.12.068

7. World Health Organization (WHO). European report on preventing child maltreatment. Copenhagen: WHO Regional Office for Europe; 2013.

8. Fegert JM, Vitiello B, Plener PL, Clemens V. Challenges and burden of the Coronavirus 2019 (COVID-19) pandemic for child and adolescent mental health: a narrative review to highlight clinical and research needs in the acute phase and the long return to normality. Child Adolesc Psychiatry Mental Health. 2020;14:1-11. https://doi.org/10.1186/s13034-020-00329 -3 .

9. Roje Dapić M, Buljan Flander G, Prijatelj K. Children behind closed doors due to COVID-19 isolation: abuse, neglect and domestic violence. Arch Psychiatry Res. 2020;56(2):181-92. https://doi.org/10.20471/ dec.2020.56.02.06.

10. Eisner M, Nivette A. Violence and the pandemic. Urgent questions for research. New York: Harry Frank Guggenheim Foundation; 2020.

11. Martinkevich P, Larsen LL, Græsholt-Knudsen T, Hesthaven G, Hellfritzsch MB, Petersen KK, Møller-Madsen B, Rölfing JD. Physical child abuse demands increased awareness during health and socioeconomic crises like COVID-19: a review and education material. Acta Orthop. 2020. https ://doi.org/10.1080/17453674.2020.1782012.

12. Campbell AM. An increasing risk of family violence during the COVID-19 pandemic: strengthening community collaborations to save lives. Forensic Sci Int Rep. 2020. https://doi.org/10.1016/j.fsir.2020.100089.

13. UNICEF. Ethical considerations for evidence generation involving children on the COVID-19 pandemic. Florence: Office of Research_-Innocenti; 2020. 
14. Peterman A, Potts A, O'Donnell M, Thompson K, Shah N, Oertelt-Prigione $S$, van Gelder N. Pandemics and violence against women and children. 2020. https://www.cgdev.org/publication/pandemics-and-violenceagainst-women-and-children.

15. Anser MK, Yousaf Z, Khan MA, Nassani AA, Alotaibi SM, Abro MM, Vo $X V$, Zaman K. Does communicable diseases (including COVID-19) may increase global poverty risk? A cloud on the horizon. Environ Res. 2020;187:109668. https://doi.org/10.1016/j.envres.2020.109668.

16. Prime $H$, Wade $M$, Browne DT. Risk and resilience in family well-being during the COVID-19 pandemic. Am. Psychol. 2020. https://content.apa.org/ fulltext/2020-34995-001.html.

17. Seddighi H, Salmani I, Javadi MH, Seddighi S. Child abuse in natural disasters and conflicts: a systematic review. Trauma Violence Abuse. 2019. https://doi.org/10.1177/1524838019835973.

18. Masten AS, Narayan AJ. Child development in the context of disaster, war and terrorism: pathways of risk and resilience. Annu Rev Psychol. 2012;63:227-57. https://doi.org/10.1146/annurev-psych-120710-100356.

19. Masten AS, Motti-Stefanidi F. Multisystem resilience for children and youth in disaster: reflections in the context of COVID-19. Advers Resil Sci. 2020;1:95-106. https://doi.org/10.1007/s42844-020-00010-w.

20. Wade M, Prime H, Browne DT. Why we need longitudinal mental health research with children and youth during (and after) the COVID19 pandemic. Psychiatry Res. 2020. https://doi.org/10.1016/j.psych res.2020.113143.

21. Singh S, Roy MD, Sinha CPTMK, Parveen CPTMS, Sharma CPTG, Joshi CPTG. Impact of COVID-19 and lockdown on mental health of children and adolescents: a narrative review with recommendations. Psychiatry Res. 2020. https://doi.org/10.1016/j.psychres.2020.113429.

22. Madigan S, Cyr C, Eirich R, Fearon RP, Ly A, Rash C, Poole JC, Alink LR. Testing the cycle of maltreatment hypothesis: meta-analytic evidence of the intergenerational transmission of child maltreatment. Dev Psychopathol. 2019;31(1):23-51. https://doi.org/10.1017/S0954579418001700.

23. Widom CS, Czaja SJ, DuMont KA. Intergenerational transmission of child abuse and neglect: real or detection bias? Science. 2015;347(6229):14805. https://doi.org/10.1126/science.1259917.

24. Olsson A, Knapska E, Lindström B. The neural and computational systems of social learning. Nat Rev Neurosci. 2020. https://doi.org/10.1038/s4158 3-020-0276-4.

25. Dodge KA, Bates JE, Pettit GS. Mechanisms in the cycle of violence. Science. 1990;250:1678-83. https://doi.org/10.1126/science.2270481.

26. Lo CKM, Chan KL, Ip P. Insecure adult attachment and child maltreatment: a meta-analysis. Trauma Violence Abuse. 2019;20(5):706-19. https://doi. org/10.1177/1524838017730579.

27. Rebellon CJ, Van Gundy K. Can control theory explain the link between parental physical abuse and delinquency? A longitudinal analysis. J Res Crime Delinq. 2005;42(3):247-74. https://doi.org/10.1177/0022427804 271926.

28. McEwen BS. Neurobiological and systemic effects of chronic stress. Chronic Stress. 2017. https://doi.org/10.1177/2470547017692328.

29. Caspi A, McClay J, Moffitt TE, Mill J, Martin J, Craig IW, Poulton R. Role of genotype in the cycle of violence in maltreated children. Science. 2002;297:851-4. https://doi.org/10.1126/science.1072290.

30. Palumbo S, Mariotti V, lofrida C, Pellegrini S. Genes and aggressive behavior: epigenetic mechanisms underlying individual susceptibility to aversive environments. Front Behav Neurosci. 2018;12:117. https://doi. org/10.3389/fnbeh.2018.00117.

31. Coulton CJ, Crampton DS, Irwin M, Spilsbury JC, Korbin JE. How neighborhoods influence child maltreatment: a review of the literature and alternative pathways. Child Abuse Negl. 2007;31(11-12):1117-42. https:// doi.org/10.1016/j.chiabu.2007.03.023.

32. Wilcox P, Cullen FT. Situational opportunity theories of crime. Ann Rev Criminol. 2018;1:123-48. https://doi.org/10.1 146/annurev-criminol-03231 7-092421.

33. Agnew R. Foundation for a general strain theory of crime and delinquency. Criminology. 1992;30(1):47-87. https://doi. org/10.1111/j.1745-9125.1992.tb01093.x

34. Finkelhor D, Asdigian NL. Risk factors for youth victimization: beyond a lifestyles/routine activities theory approach. Violence Vict. 1996;11(1):319. https://doi.org/10.1891/0886-6708.11.1.3.

35. Aneshensel CS. Social stress: theory and research. Ann Rev Sociol. 1992;18(1):15-38. https://doi.org/10.1146/annurev.so.18.080192.000311.
36. Oishi S. Socioecological psychology. Annu Rev Psychol. 2014;65:581-609. https://doi.org/10.1146/annurev-psych-030413-152156.

37. Belsky J. Child maltreatment: an ecological integration. Am Psychol. 1980;35(4):320-35. https://doi.org/10.1037/0003-066X.35.4.320.

38. Cicchetti D, Toth SL, Maughan A. An ecological-transactional model of child maltreatment. In: Sameroff AJ, Lewis M, Miller SM, editors. Handbook of developmental psychopathology. Dordrecht: Kluwer Academic Publishers; 2000. p. 689-722.

39. Camilo C, Garrido MV, Calheiros MM. The social information processing model in child physical abuse and neglect: a meta-analytic review. Child Abuse Negl. 2020;108:104666. https://doi.org/10.1016/j.chiab u.2020.104666.

40. Humphreys $\mathrm{KL}$, Myint MT, Zeanah $\mathrm{CH}$. Increased risk for family violence during the COVID-19 pandemic. Pediatrics. 2020;145(4):e20200982. https ://doi.org/10.1542/peds.2020-0982.

41. Griffith AK. Parental burnout and child maltreatment during the COVID19 pandemic. J Fam Violence. 2020. https://doi.org/10.1007/s10896-02000172-2.

42. Golberstein E, Wen H, Miller BF. Coronavirus disease 2019 (COVID-19) and mental health for children and adolescents. JAMA Pediatr. 2020. https:// doi.org/10.1001/jamapediatrics.2020.1456.

43. Patrick SW, Henkhaus LE, Zickafoose JS, Lovell K, Halvorson A, Loch S, Letterie M, Davis MM. Well-being of parents and children during the COVID19 pandemic: a national survey. Pediatrics. 2020. https://doi.org/10.1542/ peds.2020-016824.

44. Lee J. Mental health effects of school closures during COVID-19. Lancet Child Adolesc Health. 2020;4(6):421. https://doi.org/10.1016/s2352 $-4642(20) 30109-7$

45. Brown SM, Doom JR, Lechuga-Peña S, Watamura SE, Koppels T. Stress and parenting during the global COVID-19 pandemic. Child Abuse Negl. 2020. https://doi.org/10.1016/j.chiabu.2020.104699.

46. Patwardhan I, Hurley KD, Thompson RW, Mason WA, Ringle JL. Child maltreatment as a function of cumulative family risk: findings from the intensive family preservation program. Child Abuse Negl. 2017;70:92-9. https://doi.org/10.1016/..chiabu.2017.06.010.

47. Reynolds J, Wilkinson C. Accessibility of 'essential' alcohol in the time of COVID-19: casting light on the blind spots of licensing? Drug Alcohol Rev. 2020;39(4):305-8. https://doi.org/10.1111/dar.13076.

48. Labrum T, Solomon P, Marcus S. Victimization and perpetration of violence involving persons with mood and other psychiatric disorders and their relatives. Psychiatr Serv. 2020;71(5):498-501. https://doi. org/10.1176/appi.ps.201900384.

49. Cluver L, Lachman JM, Sherr L, Wessels I, Krug E, Rakotomalala S, Blight S, Hillis S, Bachmand G, Green O, Butchart A. Parenting in a time of COVID-19. Lancet. 2020;395(10231):E64. https://doi.org/10.1016/S0140 $-6736(20) 30736-4$.

50. Guedes A, Bott S, Garcia-Moreno C, Colombini M. Bridging the gaps: a global review of intersections of violence against women and violence against children. Glob Health Action. 2016;9(1):31516. https://doi. org/10.3402/gha.v9.31516.

51. Piquero AR, Riddell JR, Bishopp SA, Narvey C, Reid JA, Piquero NL. Staying home, staying safe? A short-term analysis of COVID-19 on Dallas domestic violence. Am J Crim Justice. 2020. https://doi.org/10.1007/s1210 3-020-09531-7.

52. Lindo JM, Schaller J, Hansen B. Caution! Men not at work: genderspecific labor market conditions and child maltreatment. J Public Econ. 2018;163:77-98. https://doi.org/10.1016/j.jpubeco.2018.04.007.

53. Conrad-Hiebner A, Byram E. The temporal impact of economic insecurity on child maltreatment: a systematic review. Trauma Violence Abuse. 2020:21(1):157-78. https://doi.org/10.1177/1524838018756122.

54. Usher K, Bhullar N, Durkin J, Gyamfi N, Jackson D. Family violence and COVID-19: increased vulnerability and reduced options for support. Int J Mental Health Nurs. 2020. https://doi.org/10.1111/inm.12735.

55. Gilbert R, Kemp A, Thoburn J, Sidebotham P, Radford L, Glaser D, MacMillan HL. Recognising and responding to child maltreatment. Lancet. 2009:373(9658):167-80. https://doi.org/10.1016/S0140-6736(08)61707-9.

56. Sandner M, Thomsen SL. Preventing child maltreatment: Beneficial side effects of public childcare provision. Hannover Economic Papers, 669. 2020. http://hdl.handle.net/10419/216969. 
57. Baron EJ, Goldstein EG, Wallace CT. Suffering in silence: how COVID-19 school closures inhibit the reporting of child maltreatment. J Public Econ. 2020. https://doi.org/10.2139/ssrn.3601399.

58. Wilke NG, Howard AH, Pop D. Data-informed recommendations for services providers working with vulnerable children and families during the COVID-19 pandemic. Child Abuse Negl. 2020. https://doi.org/10.1016/j. chiabu.2020.104642.

59. Ludvigsson JF. Children are unlikely to be the main drivers of the COVID19 pandemic - a systematic review. Acta Paediatr. 2020. https://doi. org/10.1111/apa.15371.

60. Wang G, Zhang Y, Zhao J, Zhang J, Jiang F. Mitigate the effects of home confinement on children during the COVID-19 outbreak. Lancet. 2020;395(10228):945-7. https://doi.org/10.1016/S0140-6736(20)30547-X.

61. Munro AP, Faust SN. Children are not COVID-19 super spreaders: time to go back to school. Arch Dis Child. 2020. https://doi.org/10.1136/archd ischild-2020-319474.

62. Larcher V, Brierley J. Children of COVID-19: pawns, pathfinders or partners? J Med Ethics. 2020. https://doi.org/10.1136/medethics-2020-10646 5.

63. Andrews DA, Bonta J. The psychology of criminal conduct. 5th ed. New Providence: LexisNexis/Matthew Bender; 2010.

64. Assink M, van der Put CE, Meeuwsen MWCM, de Jong NM, Oort FJ, Stams GJJM, Hoeve M. Risk factors for child sexual abuse victimization: a metaanalytic review. Psychol Bull. 2019;145(5):459-89. https://doi.org/10.1037/ bul0000188.
65. Van Bavel JJ, Baicker K, Boggio PS, Capraro V, Cichocka A, Cikara M, Crockett MJ, Crum AJ, Douglas KM, Druckman JN, Drury J. Using social and behavioural science to support COVID-19 pandemic response. Nat Hum Behav. 2020;4:460-71. https://doi.org/10.1038/s41562-020-0884-z.

66. Telles LE, Valença AM, Barros AJ, da Silva AG. Domestic violence in the COVID-19 pandemic: a forensic psychiatric perspective. Braz J Psychiatry. 2020. https://doi.org/10.1590/1516-4446-2020-1060.

67. Posick C, Schueths AA, Christian C, Grubb JA, Christian SE. Child victim services in the time of COVID-19: new challenges and innovative solutions. Am J Crim Justice. 2020. https://doi.org/10.1007/s12103-020-09543 -3 .

68. Mazza M, Marano G, Lai C, Janiri L, Sani G. Danger in danger: interpersonal violence during COVID-19 quarantine. Psychiatry Res. 2020. https://doi. org/10.1016/j.psychres.2020.113046.

69. Kofman YB, Garfin DR. Home is not always a haven: the domestic violence crisis amid the COVID-19 pandemic. Psychol Trauma Theory Res Pract Policy. 2020. https://doi.org/10.1037/tra0000866.

70. Bradbury-Jones $C$, Isham $L$. The pandemic paradox: the consequences of COVID-19 on domestic violence. J Clin Nurs. 2020. https://doi. org/10.1111/jocn.15296.

\section{Publisher's Note}

Springer Nature remains neutral with regard to jurisdictional claims in published maps and institutional affiliations.
Ready to submit your research? Choose BMC and benefit from:

- fast, convenient online submission

- thorough peer review by experienced researchers in your field

- rapid publication on acceptance

- support for research data, including large and complex data types

- gold Open Access which fosters wider collaboration and increased citations

- maximum visibility for your research: over $100 \mathrm{M}$ website views per year

At BMC, research is always in progress.

Learn more biomedcentral.com/submissions 